Running head: Adolescent mental health and healthy transitions to adulthood

\title{
Does positive mental health in adolescence longitudinally predict healthy transitions in young adulthood?
}

Dr Meredith O'Connor (corresponding author)

Institute of Positive Education, Geelong Grammar School; Department of Paediatrics, The University of Melbourne; Murdoch Childrens Research Institute, Royal Children's Hospital Email: mo@unimelb.edu.au 50 Biddlecombe Avenue, Corio, Victoria, Australia 3214 Tel: +61 35273 9312; Fax: +61352276242

\author{
Professor Ann V. Sanson \\ Department of Paediatrics, The University of Melbourne \\ Email: annvs@unimelb.edu.au
}

Professor John W Toumbourou

Centre for Mental Health and Wellbeing Research and School of Psychology, Deakin University, Australia.

Email: john.toumbourou@deakin.edu.au

Jacci Norrish

Institute of Positive Education, Geelong Grammar School

Email: jnorrish@ggs.vic.edu.au 
Associate Professor Craig Olsson

Centre for Mental Health and Wellbeing Research, School of Psychology, Deakin University, and Population Health, Murdoch Childrens Research Institute, Australia.

Email: craig.olsson@rch.org.au

\section{Acknowledgements}

The Australian Temperament Project is a collaboration between The University of Melbourne, the Australian Institute of Family Studies, Murdoch Childrens Research Institute, The Royal Children's Hospital, and Deakin University; further information available at www.aifs.com.au/atp. C Olsson is supported by an Australian Research Council (ARC) Senior Research Fellowship [DP130101459]. We acknowledge all collaborators who have contributed to the Australian Temperament Project, especially Margot Prior, Frank Oberklaid and Diana Smart. We would also like to thank all families involved in the ATP for their invaluable contribution to the study. Geelong Grammar School provided personnel support for this study, for authors [author] and [author]. The funding body had no role in relation to the design and conduct of the study; collection, management, analysis, and interpretation of the data; preparation, review, or approval of the manuscript; or decision to submit the manuscript for publication.

\footnotetext{
Abstract

The present study examined the longer-term implications of adolescent positive mental health for successful young adult transitions. Positive mental health in adolescence was defined by indicators roughly corresponding to Seligman's positive psychology PERMA framework (positive emotional experiences, engagement, relationships, purpose, and accomplishment), with the addition of health. Data were drawn from one of Australia's longest running studies of social and emotional development (Australian Temperament
} 
Project, est. 1983, $N=2,443$ ), which has followed a large representative community sample from infancy to 27-28 years of age. In the analyzed sample of $n=999$, positive mental health at 15-16 years was associated with indicators of career progression (educational attainment and perceived competence) and taking on citizenship responsibilities (volunteering and civic activities) over a decade later at 27-28 years. Mental health problems in adolescence were more relevant to establishing romantic partnerships in young adulthood: adolescent antisocial behaviors predicted higher likelihood of being in a relationship, while depressive symptoms predicted lower quality partnerships. The results suggest that successful transitions into young adult roles and responsibilities may be facilitated by targeted mental health promotion interventions designed to both foster positive mental health and address mental health difficulties in adolescence.

\section{Keywords}

positive mental health; internalizing and externalizing problems; positive psychology; PERMA; positive education; developmental tasks; young adulthood; emerging adulthood; longitudinal

As well as being an important outcome in its own right, positive mental health during the adolescent period may also carry implications for functioning in subsequent developmental periods, and be an asset that helps young people to meet the significant demands they are likely to face as they move into young adulthood (Schulenberg, Bryant, \& O'Malley, 2004). Indeed, there is growing interest in the potential to promote healthy pathways into adulthood through adolescent school-based interventions targeting positive mental health (O'Connor et al., in press), often referred to as positive education or resiliency programs (Norrish, Williams, O'Connor, \& Robinson, 2013). Despite this interest, there have 
been relatively few empirical explorations of how positive mental health in adolescence can be measured and whether it predicts young people's capacity to more successfully meet the key challenges of the young adulthood period, which includes challenges such as establishing meaningful work, forming romantic relationships, and becoming an active member of the community. The present study aims to address this gap and explore whether positive mental health in adolescence - indicated by positive emotional experiences, engagement, relationships, meaning, and accomplishment (Seligman's (2011) positive psychology PERMA framework), and health - predict healthy young adult transitions. To investigate this, we capitalize on observational data from one of Australia's most mature longitudinal studies of social and emotional development - The Australian Temperament Project (ATP) - which now spans over three decades of data collection (Edwards et al., 2013). Understanding these relationships will help to explicate the potential legacy and return on investment of adolescent-focused mental health promotion programs.

\section{Positive mental health in adolescence}

The need to support the mental health and wellbeing of adolescents is attracting increased attention in both research and practice settings. Adolescence is often viewed as a critical juncture in the emergence and trajectory of mental illness (Paus, Keshavan, \& Giedd, 2008), and rates of mental health problems, especially depression and anxiety, are consistently reported as problematically high (Sawyer, Miller-Lewis, \& Clark, 2007). Equally important to the prevention of ill-health is building good health and wellbeing, and young people who do not have a diagnosable disorder may nevertheless not be functioning at their optimal level (Suldo, Thalji, \& Ferron, 2011). For example, in a large sample of American adolescents, Keyes (2006) found that over half did not meet criteria for optimal mental health, and rates decreased as adolescents progressed to older ages. 
Responding to these issues, positive education is a newly emerging framework that, broadly speaking, refers to the application of positive psychology within the school setting (Seligman, Ernst, Gillham, Reivich, \& Linkins, 2009). Positive education interventions target physical health and five domains of positive mental health roughly aligning to Seligman's (2011) PERMA framework: positive emotional experiences or emotional wellbeing including developing healthy responses to difficult emotions; engagement and immersion in activities; social skills for healthy relationships; purpose through service to others; and accomplishment of meaningful goals (Norrish et al., 2013). The PERMA model aligns with the recognized multidimensionality of positive mental health and the need to consider both the individual and their relationships to their social contexts, and has received some empirical support in use with adolescents (Kern, Waters, Adler, \& White, 2015). These domains are targeted within explicit positive education curriculum in dedicated class time, implicit teaching embedded into the academic curriculum across a broad range of subjects, and systemically focused school-wide practices.

In the short term, the goal of positive education is for students to thrive both psychologically and academically at school (Seligman et al., 2009). In the longer term, however, such programs aim to equip students with the skills and competencies they will need once they leave the school setting, allowing them to become flourishing adults successfully self-managing emotional challenges to make sound choices and leading fulfilling lives that contribute socially and economically to society (O'Connor et al., in press). Adaptive functioning in one developmental period is expected to promote continued wellbeing in the next (Masten \& Tellegen, 2012), and looking to opportunities for intervention prior to young people stepping out into adult roles may allow them to build up strong capacities and skills so that they are ready and equipped to tackle the significant challenges that lie ahead. Prevention and promotion efforts in adolescence also mean that 
there are more opportunities for universal mental health intervention delivery through the education platform, in contrast to the difficulties in reaching all young adults given their lack of engagement in a singular institution. Primary and secondary schools may therefore be uniquely placed to deliver positive mental health interventions that promote healthy developmental pathways through the transition to adulthood.

\section{Key challenges in young adulthood}

Becoming a fully engaged young adult within society (a role that young people in the Western world are currently expected to begin taking up around their late 20s) is reflected by progress towards meeting the key developmental tasks of this period. The concept of developmental tasks has a long history in psychology and education (Havighurst, 1956), and generally refers to normative or culturally defined activities or goals expected during certain periods of the life course (McCormick, I-Chun Kuo, \& Masten, 2011; Schulenberg et al., 2004). Key tasks during the young adult period include establishing a career, forming romantic relationships, and becoming an active member of the community (Roisman, Masten, Coatsworth, \& Tellegen, 2004; Schulenberg et al., 2004; Schulenberg \& Maggs, 2002; Seiffge-Krenke \& Gelhaar, 2008).

Young adults' engagement with these salient tasks carries social and economic implications for both individuals and society (Settersten, 2005). The capacity of individuals to take up the responsibilities of citizenship and become involved community members is essential for a successful democratic society, and can contribute to economic growth, effective political institutions, and lower crime rates (Brehm \& Rahn, 1997). Although at an increasingly older age, society also relies on young adults to eventually establish a career path; when this fails to occur, youth unemployment costs society in terms of economic prosperity (Watts \& Mitchell, 2000), and costs individuals in terms of poorer psychological and physical health outcomes (McKee-Ryan, Song, Wanberg, \& Kinicki, 2005). Establishing 
healthy romantic partnerships is also considered a key task of young adulthood (Rauer, Pettit, Lansford, Bates, \& Dodge, 2013), and carries implications for both psychological and physical health outcomes (Kiecolt-Glaser \& Newton, 2001).

A number of studies support the hypothesis that positive mental health in adolescence provides a strong foundation that helps young people to engage with these challenges as they enter young adulthood. Schulenberg et al. (2004) found that in a US sample, senior secondary school students on a stronger trajectory of wellbeing (self-esteem, self-efficacy, and social support) had greater success in achieving developmental tasks in the areas of work, romantic involvement, and citizenship at age 26. Looking at a sample already transitioned from the school context, Hawkins et al. (2012) found that healthy psychosocial functioning at 19-20 years (operationalized along social, emotional, and community engagement dimensions), predicted emotional health, physical well-being, peer relationship quality, lower levels of antisocial behavior and continued wellbeing at 23-24 years. Masten, Desjardins, McCormick, Kuo, and Long (2010) found that competence in childhood and adolescence, operationalized as success in the areas of rule abiding conduct, social competence, and academic achievement, predicted successful engagement in paid work at 30 years of age.

On the other hand, there are also some reasons to question whether students experiencing positive mental health in adolescence will necessarily be excelling in the tasks of young adulthood. There is a significant degree of discontinuity in development observed during the transition from adolescence to adult life (Masten et al., 2004; Schulenberg et al., 2004). School systems are geared towards managing students' behavior but these highly structured behavioral scaffolds fall away as young people make the transition to adulthood, which is characterized by a profound lack of institutional support (Arnett, 2006; Cote, 2006). Hence, once young people leave the school setting they are more reliant on their own resources and to some extent must be able to stand alone as an independent person, capable 
of making choices from a wide range of possibilities (Arnett, 2006; Cote, 2006). Consistent with this challenge, relatively high incidences of problem outcomes are observed during the transition to adulthood (Kessler \& Walters, 1998). Helping to equip young people with the skills and competencies that they need to negotiate this transition period is therefore an imperative.

\section{The current study}

Positive mental health in adolescence has been targeted as both an important outcome in its own right, and as a potential leverage point to promote healthy pathways into adulthood (O’Connor et al., in press). However, the longer-term implications of adolescent positive mental health for young adult outcomes have yet to be sufficiently tested, likely due to the dearth of longitudinal data spanning these developmental periods. Hence, the potential legacy of adolescent positive mental health programs (such as the increasingly popular positive education initiatives) in preparing young people for adulthood remains unclear. In the present study we capitalize on data collected through the ATP, which has followed a representative community sample of young people from infancy to 27-28 years of age, over 15 waves of data collection. This provides a unique opportunity to explore the long term outcomes of adolescent wellbeing for young adult functioning.

\section{Method}

\section{Participants and Procedure}

Participants were members of the ATP, a large scale prospective longitudinal study of children's temperament and development. The sample was recruited from Maternal and Child Health Centers in 1983, and comprised a representative sample of 2,443 infants (aged 4-8 months) and their parents from urban and rural areas of the state of Victoria, Australia. Details on methods and procedures are provided in Prior et al. (2000). Briefly, families have been surveyed by mail every one to two years until 19 years of age and every four years 
thereafter with a total of 15 waves of surveys completed to date (Edwards et al., 2013). The present study focuses on the self-report responses from the $n=999$ young people $(60.4 \%$ female) who completed the survey in 2010 at 27-28 years; most of these participants had also completed the data collection wave at $15-16$ years $(n=844,84 \%)$.

Study attrition. Attrition in the ATP has occurred at a rate of around $1 \%$ per annum, which is comparable to similar long term cohorts worldwide. The sample continues to include young adults with a broad range of attributes and from diverse circumstances. Of 2443 participants at commencement in 1983, around 1700 are still enrolled in the study after three decades (the retained sample). Characteristics of the retained sample at the 15 th wave as compared with the original sample upon recruitment demonstrates that proportionately more families from a lower SES-background, or parents who were not born in Australia, have been lost to the study (Hawkins et al., submitted). For example, $19.2 \%$ of the original sample fell in the lowest socioeconomic grouping, compared to $12.7 \%$ of those still enrolled in 2010. However, attrition analyses on other indicators indicated no differences; for example temperament style in infancy $(\mathrm{t}[2,441]=1.96, \mathrm{p}=.05, \mathrm{~ns})$ and behavioral problems during infancy $(\mathrm{t}[2,432]=0.045, \mathrm{p}=.96, \mathrm{~ns})$. Of the retained sample, $\mathrm{n}=999$ participated in the Wave 15 data collection.

Recently, comprehensive analyses have been conducted to further investigate the potential for study attrition to introduce bias within the ATP, focusing on participants' retrospective reports of child maltreatment, which are particularly susceptible to bias from loss to follow up (Doidge, unpublished manuscript). The findings suggest that while loss to follow up may introduce bias into estimates of the prevalence and correlates of child maltreatment, the extent was mostly minimal and unlikely to change study conclusions. Given the focus in the current study was on normative developmental pathways rather than 
specific vulnerable subpopulations, the introduction of bias from attrition is likely to be even lower.

\section{Measures}

An overview of the measures examined in this study is provided in Table 1. Measures were based on valid and reliable instruments considered developmentally appropriate at each specific time point. Cronbach's alphas for the current sample are provided in Table 1, and the references listed with each indicator provide further details relating to validity. Further information about measures can also be found in Edwards et al. (2013) and Prior et al. (2000), and an overview of the study methodology is available at www3.aifs.gov.au/atp/about/about.html.

\section{INSERT TABLE 1 ABOUT HERE}

Positive mental health at $\mathbf{1 5 - 1 6}$ years. In order to make our findings as relevant as possible to current practice, we aligned our measure of positive mental health with that put forward by Norrish et al. (2013) for use in adolescent positive education programs, using indicators of the six domains of emotional wellbeing, engagement, social skills for healthy relationships, purpose, accomplishment, and behaviors promoting physical health (Norrish et al., 2013). These domains roughly correspond to Seligman's (2011) PERMA model, with the addition of health. Details of these indicators and other study measures are presented in Table 1.

Young adult developmental tasks at 23-24 and 27-28 years. From the literature, three domains of developmental tasks were identified that reflect socially meaningful accomplishments in young adulthood, including establishing a career (Roisman et al., 2004; Schulenberg et al., 2004; Schulenberg \& Maggs, 2002), forming a romantic relationship (Roisman et al., 2004; Schulenberg et al., 2004; Schulenberg \& Maggs, 2002; Seiffge-Krenke \& Gelhaar, 2008), and becoming an active member of the community (Roisman et al., 2004; 
Schulenberg et al., 2004; Schulenberg \& Maggs, 2002; Seiffge-Krenke \& Gelhaar, 2008). Multiple indicators of progress towards each task domain were available in the dataset, and details of these are presented in Table 1. We took outcomes from both 23-24 years and 27-28 years, with the exception of establishing a career, where no meaningful data was available at 23-24 years.

Demographics and control variables (15-16 years). Parents provided reports on indicators of family makeup, stress, and socioeconomic resources, while the study participant provided reports of internalizing and externalizing problems at 15-16 years (see Table 1).

\section{Data analysis}

Missing data across the variables averaged 11.7\%; this was accounted for using Full Information Maximum Likelihood (FIML) when conducting the Confirmatory Factor Analysis, and complete case analysis in the subsequent regressions. The Confirmatory Factor Analysis (CFA) of the positive mental health construct was performed using AMOS 20 software (Arbuckle, 2007). Model estimations were based on a covariance matrix and used maximum likelihood estimates, suitable for large sample sizes (Tabachnick \& Fidell, 2001). A number of fit statistics that indicate how well the model reflects the data are reported (Schreiber, Nora, Stage, Barlow, \& King, 2006). Chi-square is the most commonly reported fit statistic and significant chi-square values suggest that the sample correlation matrix and the model correlated matrix are significantly different; however, it is known to be effected by large sample size. The Root Mean Square Error of Approximation (RMSEA) with an associated $90 \%$ confidence interval is based on the non-centrality parameter, and takes particular account of the error of approximation, with values up to .06 indicating acceptable fit. The Comparative Fit Index (CFI) is derived from comparison of a hypothesized model with the independence (or null) model, and values above .95 suggest an adequate model fit. Once a good model fit was achieved, a latent factor score was computed from the positive 
mental health latent construct, and this score was used as a predictor in the subsequent regression analyses conducted in SPSS 22.0.

\section{Results}

Results are presented in two parts. First, results of the Confirmatory Factor Analysis (CFA) are described, which allowed a latent factor score on the positive mental health construct to be derived for each participant. Second, estimates from a series of logistic or linear regression models (depending on whether the outcome was dichotomous or continuous) and presented, with positive mental health scores examined as a predictor of success in meeting three key tasks in young adulthood (23-24 and 27-28 years): 1) establishing a career, 2) forming romantic relationships, and 3) becoming an active citizen.

\section{Deriving the measure of positive mental health at 15-16 years}

We conducted a CFA on the indicators of positive mental health at 15-16 years in order to derive latent factor scores of adolescent positive mental health, for use in the subsequent analysis. In the CFA, the Positive mental health latent factor was indicated by the six observed variables of Emotions, Engagement, Relationships, Purpose, Accomplishment, and Health (see Figure 1). Loadings of the observed variables on the Positive Mental Health construct in this model were all significant and ranged from .19 to .80 . While the loading of Relationships on the factor was lower (.19), it was expected that there would be variation in loadings across the dimensions, and this loading was still considered to be making a meaningful contribution. Modification Indices suggested the addition of two correlated error covarainces (where two indicators covary for reasons other than the influence of the shared latent factor), which were deemed theoretically justifiable. The correlation of the residual errors for Accomplishment and Engagement was allowed because these variables were measured using the same question stem and response format, therefore sharing method variance extraneous to the model. Similarly, the correlation between the residual error terms 
for Relationships and Emotions was considered justifiable, because of the similarity in response format. This CFA was an excellent fit for the data by all fit measures examined, with the exception of $\chi^{2}$ which is known to be influenced by large sample size $\left(\chi^{2}(7)=45.57\right.$, $p<.001 ; \mathrm{RMSEA}=.05,90 \% \mathrm{CI}=.03-.06 ; \mathrm{CFI}=.98)$.

\section{INSERT FIGURE 1 ABOUT HERE}

Using model-based imputation in AMOS, a latent factor score was computed from the Positive mental health factor in this model, and this score $(M=.00, S D=.25)$ was used as a predictor in the subsequent regression analyses. Deriving latent factor scores in this way can provide a more accurate and robust indication of the underlying construct than more traditional techniques such as calculating the mean. To test the validity of this newly derived measure we correlated it against concurrent indicators of internalizing and externalizing problems, and found it to correlate at $r=-.39(p<.001)$ with symptoms of depression, and $r=-$ $.40(\mathrm{p}<001)$ with anti-social behaviors, which is similar to previous observations of a moderate negative relationship between positive mental health and concurrent internalizing and externalizing pathology (O'Connor et al., 2012; O'Connor, Sanson, Hawkins, Toumbourou, et al., 2011).

\section{Positive mental health in adolescence as a predictor of progress towards meeting developmental tasks in young adulthood}

Next, we explored adolescent positive mental health scores derived from the CFA as a predictor of progress in the areas of work, romantic relationships, and civic engagement in young adulthood. Logistic or linear regression analyses were conducted depending on the nature of each outcome variable (dichotomous or continuous). Each model was adjusted for potential confounders including demographics, socioeconomic resources, family stress, family structure, and internalizing and externalizing problems at 15-16 years (see Table 1). Multiple outcomes relating to each developmental task were available at 23-24 and 27-28 
years of age, and hence a series of regressions were conducted, grouped according to domain in Tables 2-4.

Establishing a career. As illustrated in Table 2, positive mental health at 15-16 years was identified as a unique predictor of multiple indicators of young people's progress towards establishing a career path by $27-28$ years of age (no data on career progression was available at 23-24 years). Young people with higher levels of positive mental health in adolescence tended to achieve higher levels of education and report greater job competence at 27-28 years. These effects were evident even when controlling for a broad range of covariates at 15-16 years, including symptoms of depression and anti-social behaviors. Family disadvantage and anti-social behavior also predicted lower educational attainment, and depression was associated with lower job satisfaction. The amount of variance accounted for was relatively modest (3-20\%), which is perhaps unsurprising given that the outcomes were measured over a decade after the predictors.

\section{INSERT TABLE 2 ABOUT HERE}

Forming romantic relationships. A different picture emerged in relation to success in forming romantic relationships at 27-28 years, with no significant associations between positive mental health in adolescence and relationship outcomes in young adulthood observed (see Table 3). Internalizing and externalizing issues in adolescence appeared to be far more relevant; at both time points anti-social behaviors predicted higher likelihood of being in a relationship, and depression predicted reduced relationship quality. Young women were more likely to both be in a relationship and report higher relationship quality at 23-24 years, but this gender difference was no longer evident by 27-28 years.

\section{INSERT TABLE 3 ABOUT HERE}

Taking on the responsibilities of citizenship. Young people who had experienced high levels of positive mental health in adolescence were observed to have greater likelihood 
of engaging in citizenship behaviors at both 23-24 and 27-28 years, and volunteering at 27-28 years (see Table 4). Antisocial behaviors in adolescence predicted reduced engagement with volunteering at 27-28 years, while young women were more likely to engage in civic activities. There was a mixed picture in relation to socioeconomic resources, with disadvantage predicting earlier volunteering, while relative advantage was associated with greater involvement with civic activities and longer-term volunteering at 27-28 years.

\section{INSERT TABLE 4 ABOUT HERE}

\section{Discussion}

The current findings reveal in a large longitudinal study that positive mental health during the adolescent period was a measurable asset that predicted stronger engagement with two important domains of young adult development: establishing a career and taking on the responsibilities of citizenship. In contrast, internalizing and externalizing problems during adolescence were more predictive of success in forming positive romantic partnerships. Thus, the findings suggest that, as argued by O'Connor et al. (in press), the promotion of positive mental health in adolescence may indeed be an effective intervention target for promoting more adaptive pathways into adulthood. However, the present findings also challenge adolescent positive education and resiliency programs to address positive interventions that encourage the capacity for thriving, while not neglecting targeted interventions to reduce problems. A balanced mix of interventions may offer advantages to effectively prepare adolescents for the challenges that lie ahead on the path to adulthood.

Consistent with the idea that adaptive functioning in one developmental period is expected to promote continued wellbeing in the next (Masten \& Tellegen, 2012), we found that positive mental health in adolescence (15-16 years) was a salient predictor of progress towards establishing a career at 27-28 years, even after accounting for a range of developmental, demographic and family characteristics at baseline. Positive adolescent 
mental health predicted young adult higher educational attainment and perceived competence in their current job. It may be that positive mental health in adolescence helps students to achieve better academic outcomes (Howell, 2009; Suldo et al., 2011), thus fostering stronger educational and occupational pathways in early adulthood (Pinquart, Juang, \& Silbereisen, 2003). These effects were independent of the association with mental health problems, which were also uniquely associated with educational attainment and job satisfaction.

Positive mental health in adolescence additionally predicted engagement with civically oriented activities at 23-24 and 26-27 years, and volunteering at 27-28 years. This accords with previous observations of an orientation towards working for the community in late adolescence predicting stronger positive developmental outcomes in the first few years out of high school (O'Connor, Sanson, Hawkins, Letcher, et al., 2011). Again, these effects were observed even once controlling for adolescent mental health problems, with only antisocial behaviors predicting volunteering at 27-28 years. An important aspect of positive mental health in adolescence is not just 'feeling good,' but making meaningful contributions back to the community (Lerner et al., 2005). In turn, adolescent civic engagement can promote later civic mindedness by helping young people to develop the norms, attitudes, and skills conducive to later adult political and civic participation (Smith, 1999).

In contrast, positive mental health was not observed to have any relationship to progress in establishing positive romantic relationships, while mental health problems were consistently predictive. Antisocial behaviors at 15-16 years in fact predicted higher odds of being in a relationship at 23-24 and 27-28 years. Rauer et al. (2013) similarly found that adolescents involved with antisocial peers were more likely to be in romantic relationships as young adults. It would be of interest in future research to further explore the mechanisms underlying this association; for example, whether factors such as impulsivity and thrill seeking, which are associated with both delinquency and engagement with romantic 
relationships, may mediate this relationship (Eklund, Kerr, \& Stattin, 2010). Depressive symptoms were negatively related to the more critical outcome of relationship quality. Vujeva and Furman (2011) found that heightened depressive symptoms at 15 years of age was associated with both more relationship conflict and less positive problem solving skills by the early 20 s, suggesting that adolescent depression may get in the way of developing newly emerging relationship conflict resolution and positive problem solving skills (Vujeva \& Furman, 2011).

While the focus of the present paper was on positive mental health, the findings speak to the need to consider the dual continuum of mental health when considering approaches to promoting strong adult pathways. The dual continuum approach conceptualizes positive mental health and mental health difficulties as two related but distinct continuums, and has received strong empirical support (O'Connor et al., 2012; O'Connor, Sanson, Hawkins, Toumbourou, et al., 2011). On the positive mental health side, our findings strikingly illustrate the positive youth development tenet that "problem free is not fully prepared" (Pittman \& Fleming, 1991: p. 3), as mental health competencies in adolescence were stronger and more consistent predictors of employment and citizenship outcomes than mental health problems. On the difficulties side, depressive symptoms in adolescence may be particularly relevant in disrupting the development of newly emerging skills within romantic relationships. Both the positive and difficulties side of adolescent mental health must therefore be considered if we are to promote healthy pathways into adulthood.

It is also worth noting the demographic predictors of young adult outcomes observed in our results. Family socioeconomic position was the strongest predictor of educational achievement in young adulthood, consistent with a large body of research, likely attributable to a range of factors such as parental educational attainment, differences in the home learning environment, and attendance at lower resourced schools (Burney \& Beilke, 2008). In 
addition, disadvantage predicted consistently lower participation in civic activities in young adulthood; this has been previously observed and appears to be intertwined with educational attainment (Flanagan \& Levine, 2010). Targeting social and emotional skills for children from disadvantaged backgrounds may be an opportunity to promote more equitable young adult outcomes, such as educational success (Reyes, Elias, Parker, \& Rosenblatt, 2013), and this should be a key area for future research. Gender also appeared to play a role, with young men faring worse than young women across a number of young adult outcomes, suggesting that opportunities to promote young men's health may require further consideration.

\section{Implications}

Looking to opportunities for intervention prior to young people stepping out into adult roles can help young people to build up strong capacities and skills so that they are ready and equipped to tackle the significant challenges that lie ahead, and allow us to capitalize on opportunities for universal program delivery through the education platform. The current findings suggest that intervening to promote domains of positive mental health in adolescence may indeed be a viable way of promoting healthy pathways into adulthood.

Strategies that address both the promotion of positive mental health and prevention of mental health problems in adolescence are likely to be needed to promote the best possible young adult outcomes. Consistent with the dual continuum model, we found that adaptation in young adulthood is healthiest when young people have the opportunity to experience both positive mental health and be relatively untroubled by symptoms of psychopathology. A balanced approach that incorporates both promotion-based and problem-focused strategies is needed in schools to develop more integrated intervention agendas.

The findings also carry implications for conceptualization of healthy development in adolescence. The results of this study suggest that health and domains similar to Seligman's (2011) PERMA model of positive emotions, engagement, relationships, purpose, and 
accomplishment can be accurately modeled as a measure of positive mental health in adolescence, and shows promising long-term predictive validity. This supports the model of positive mental health currently used in positive education (Norrish et al., 2013), and the need for comprehensive and multi-faceted approaches to building and protecting mental health in school contexts (as opposed to programs focused on only one or a few concepts). Another key feature of these results is the centrality of civic responsibility as both an indicator of positive mental health during adolescence (via the meaning domain) and as an important developmental task in young adulthood. This supports the importance of eudaimonic behaviors for mental health (Hallam et al., 2014), and highlights the potential benefits of supporting and encouraging young people to engage in volunteering and civic focused behaviors.

While following the path of young people after they leave school is difficult, future research could track young people with high mental health at adolescence who show less promising trajectories (i.e. discontinuity) into young adulthood, and vice versa, to try to elucidate the factors that support and/or hinder young people to thrive once they have left the stability of the school context. Identifying young people with low levels of mental health in the adolescent life stage and trialing bridging interventions to support them as they work towards young adulthood could also be a fruitful area for investigation.

\section{Strengths and limitations}

This study capitalizes on high-quality longitudinal data to address important research questions. Strengths of the data include the relatively large sample size, nuanced and multidimensional assessment of adolescent wellbeing, and the breadth of information available that has allowed for a wide range of potential confounders to be accounted for in the analyses. As always, however, there are limitations to be born in mind when interpreting associations within this observational paradigm, and we are unable to make definitive 
inferences regarding causality. To capitalize on this data we retrofitted a positive mental health construct onto the measures that had been collected at the 1998 wave of the ATP. While overall this construct was found to fit the data very well, we did have some difficulty in relation to the health dimension, where we could only take the absence of risk behaviors (e.g. refraining from smoking) rather than the true presence of health promoting behaviors (like regular exercise). Similarly, at the young adult period we were again restricted by the data available, and hence had to rely on some cruder measures than would be ideal. Finally, because attrition was higher among the most disadvantaged families the role of socioeconomic status may be slightly underestimated in these analyses, though overall attrition is unlikely to have a significant impact on the results given that the sample remains broadly representative.

\section{Conclusions}

Positive mental health in adolescence has been targeted as both an important outcome in its own right, and as a potential leverage point to promote healthy pathways into adulthood (O’Connor et al., in press). However, the longer-term implications of adolescent positive mental health for young adult outcomes have previously been insufficiently tested, so that the potential legacy of adolescent positive mental health programs in preparing young people for adulthood remains unclear. In the present study we capitalized on data collected through the ATP, which has followed a representative community sample of young people from infancy to 27-28 years of age, over 15 waves of data collection. We were able to operationalize a positive mental health indicator at 15-16 years, and this predicted success in establishing a career and taking on citizenship responsibilities over a decade later. However, mental health problems in adolescence were more relevant to establishing romantic partnerships in young adulthood. The results demonstrate the importance of taking into account both the promotion of positive outcomes and prevention of difficulties when considering the potential of 
adolescent mental health initiatives to prepare young people for the challenges of the young adult period. 


\section{Figure captions}

Fig 1 Confirmatory Factor Analysis of positive mental health in adolescence (15-16 years) 


\section{References}

Ainley, J., Reed, R., \& Miller, H. (1984). School organisation and the quality of schooling: A study of Victorian Government secondary schools. ACER Research Monograph, 29.

Angold, A., Costello, E. J., Messer, S. C., Pickles, A., Winder, F., \& Silver, D. (1995).

Development of a short questionnaire for use in epidemiological studies of depression in children and adolescents. International Journal of Methods in Psychiatric Research, 5, 237-249.

Arbuckle, J. (2007). Amos 16.0 user's guide. USA: Amos Development Corporation.

Arnett, J. (2006). Emerging adulthood: Understanding the new way of coming of age. In J. Arnett \& J. Tanner (Eds.), Emerging adults in America: Coming of age in the 21st century (pp. 3-20). Washington: American Psychological Association.

Braiker, H. B., \& Kelley, H. H. (1979). Conflict in the development of close relationships. Social exchange in developing relationships, 135-168.

Brehm, J., \& Rahn, W. (1997). Individual level evidence for the causes and consequences of social capital. American Journal of Political Science, 41(3), 999-1023.

Broom, L., Jones, F. L., \& Zubrzycki, J. (1976). Opportunity and attainment in Australia. Canberra: ANU Press.

Brotherton, P. I., Kotler, T., \& Hammond, S. B. (1979). Development of an Australian index of social class. Australian Psychologist, 14, 77-83.

Burney, V. H., \& Beilke, J. R. (2008). The Constraints of Poverty on High Achievement. Journal for the Education of the Gifted, 31(3), 171-197.

Cote, J. (2006). Emerging adulthood as an institutionalised moratorium: Risks and benefits to identity formation. In J. Arnett \& J. Tanner (Eds.), Emerging adults in America: Coming of age in the 21st century (pp. 85-116). Washington, DC: American Psychological Association. 
Doidge, J. (unpublished manuscript). Implications of missing data in research on child maltreatment.

Edwards, B., Hawkins, M., Letcher, P., Little, K., Macdonald, J., Oberklaid, F., . . Sanson, A. (2013). The Australian temperament project: The first 30 years. Melbourne, Australia: Australian Institute of Family Studies.

Eklund, J. M., Kerr, M., \& Stattin, H. (2010). Romantic relationships and delinquent behaviour in adolescence: The moderating role of delinquency propensity. Journal of adolescence, 33(3), 377-386.

Flanagan, C., \& Levine, P. (2010). Civic engagement and the transition to adulthood. The future of children, 20(1), 159-179.

Gresham, F., \& Elliot, S. (1990). Manual for the Social Skills Rating System. Circle Pines, MN: American Guidance Service.

Hallam, W., Olsson, C., O’Connor, M., Hawkins, M., Toumbourou, J., Bowes, G., . . . Sanson, A. (2014). Association Between Adolescent Eudaimonic Behaviours and Emotional Competence in Young Adulthood. Journal of Happiness Studies, 15(5), 1165-1177. doi: 10.1007/s10902-013-9469-0

Havighurst, R. J. (1956). Research on the developmental-task concept. The School Review, 64(5), 215-223.

Hawkins, M., Letcher, P., O'Connor, M., Bant, S., Deery, A., Sanson, A., . . Olsson, C. (submitted). The nature and stability of positive development across young adulthood: Longitudinal findings from the Australian Temperament Project.

Hawkins, M., Villagonzalo, K., Sanson, A., Toumbourou, J., Letcher, P., \& Olsson, C. (2012). Associations between positive development in late adolescence and social, health, and behavioral outcomes in young adulthood. Journal of Adult Development, 19(2), 88-99. 
Howell, A. J. (2009). Flourishing: Achievement-related correlates of students' well-being. Journal of Positive Psychology, 4, 1-13.

Kern, M. L., Waters, L. E., Adler, A., \& White, M. A. (2015). A multidimensional approach to measuring well-being in students: Application of the PERMA framework. The Journal of Positive Psychology, 10(3), 262-271.

Kessler, R., \& Walters, E. (1998). Epidemiology of DSM-III-R major depression and minor depression among adolescents and young adults in the National Comorbidity Survey. Depression and Anxiety, 7(1), 3-14.

Keyes, C. (2006). Mental health in adolescence: is America's youth flourishing? American Journal of Orthopsychiatry, 76(3), 395-402.

Kiecolt-Glaser, J. K., \& Newton, T. L. (2001). Marriage and health: his and hers. Psychological Bulletin, 127(4), 472.

Lerner, R., Lerner, J., Almerigi, J., Theokas, C., Phelps, E., Gestsdottir, S., . . Ma, L. (2005). Positive Youth Development, Participation in community youth development programs, and community contributions of fifth-grade adolescents findings from the first wave Of the 4-H study of Positive Youth Development. The Journal of Early Adolescence, 25(1), 17-71.

Masten, A., Burt, K., Roisman, G., Obradović, J., Long, J., \& Tellegen, A. (2004). Resources and resilience in the transition to adulthood: Continuity and change. Development and psychopathology, 16(4), 1071-1094.

Masten, A., Desjardins, C., McCormick, C., Kuo, S., \& Long, J. (2010). The significance of childhood competence and problems for adult success in work: A developmental cascade analysis. Development and psychopathology, 22(03), 679-694. 
Masten, A., \& Tellegen, A. (2012). Resilience in developmental psychopathology: contributions of the Project Competence Longitudinal Study. Development and Psychopathology, 24(2), 345.

McCormick, C., I-Chun Kuo, S., \& Masten, A. (2011). Developmental tasks across the lifespan. In K. Fingerman (Ed.), Handbook of life-span development (pp. 117-140). New York, USA: Springer Publishing Company.

McKee-Ryan, F., Song, Z., Wanberg, C. R., \& Kinicki, A. J. (2005). Psychological and physical well-being during unemployment: a meta-analytic study. Journal of applied psychology, 90(1), 53.

Moffitt, T. E., \& Silva, P. A. (1988). Self-reported delinquency: Results from an instrument for New Zealand. Australian \& New Zealand Journal of Criminology, 21(4), 227-240. doi: $10.1177 / 000486588802100405$

Norrish, J. M., Williams, P., O'Connor, M., \& Robinson, J. (2013). An applied framework for Positive Education. International Journal of Wellbeing, 3(2), 147-161. doi: 10.5502/ijw.v3i2.2

O'Connor, M., Sanson, A., Hawkins, M., Letcher, P., Toumbourou, J., Smart, D., . . . Olsson, C. (2011). Predictors of positive development in emerging adulthood. Journal of Youth and Adolescence, 40, 860-874. doi: 10.1007/s10964-010-9593-7

O'Connor, M., Sanson, A., Hawkins, M., Olsson, C., Frydenberg, E., Toumbourou, J., \& Letcher, P. (2012). The relationship between positive development and psychopathology during the transition to adulthood: A person-centred approach. Journal of Adolescence, 35(3), 701-712. doi: 10.1016/j.adolescence.2011.10.006

O'Connor, M., Sanson, A., Hawkins, M., Toumbourou, J., Letcher, P., \& Frydenberg, E. (2011). Differentiating three conceptualisations of the relationship between positive 
development and psychopathology during the transition to adulthood. Journal of Adolescence, 34, 475-484. doi: 10.1016/j.adolescence.2010.06.005

O’Connor, M., Sanson, A., Toumbourou, J., Hawkins, M., Letcher, P., Williams, P., \& Olsson, C. (in press). Positive development and resilience in emerging adulthood. In J. Arnett (Ed.), The Oxford Handbook of Emerging Adulthood: Oxford University Press.

Paus, T., Keshavan, M., \& Giedd, J. N. (2008). Why do many psychiatric disorders emerge during adolescence? Nature Reviews Neuroscience, 9(12), 947-957.

Pinquart, M., Juang, L. P., \& Silbereisen, R. K. (2003). Self-efficacy and successful schoolto-work transition: A longitudinal study. Journal of vocational behavior, 63(3), 329346.

Pittman, K., \& Fleming, W. (1991). A new vision: Promoting youth development. Testimony by Karen J. Pittman before the House Select Committee on Children, Youth, and Families. Washington, DC: Centre for Youth Development and Policy Research.

Prior, M., Sanson, A., Smart, D., \& Oberklaid, F. (2000). Pathways from infancy to adolescence: Australian Temperament Project 1983 - 2000. Melbourne, Victoria: Australian Institute of Family Studies.

Rauer, A. J., Pettit, G. S., Lansford, J. E., Bates, J. E., \& Dodge, K. A. (2013). Romantic relationship patterns in young adulthood and their developmental antecedents. Developmental psychology, 49(11), 2159.

Reyes, J. A., Elias, M. J., Parker, S. J., \& Rosenblatt, J. L. (2013). Promoting Educational Equity in Disadvantaged Youth: The Role of Resilience and Social-Emotional Learning. Handbook of Resilience in Children (9781461436607), 349.

Roisman, G., Masten, A., Coatsworth, D., \& Tellegen, A. (2004). Salient and emerging developmental tasks in the transition to adulthood. Child Development, 75, 123-133. 
Sawyer, M. G., Miller-Lewis, L. R., \& Clark, J. (2007). The mental health of 13-17 year-olds in Australia: findings from the National Survey of Mental Health and Well-being. Journal of Youth and Adolescence, 36(2), 185-194.

Schreiber, J. B., Nora, A., Stage, F. K., Barlow, E. A., \& King, J. (2006). Reporting structural equation modeling and confirmatory factor analysis results: A review. The Journal of Educational Research, 99(6), 323-338.

Schulenberg, J., Bryant, A., \& O'Malley, P. (2004). Taking hold of some kind of life: How developmental tasks relate to trajectories of well-being during the transition to adulthood. Development and psychopathology, 16(04), 1119-1140. doi: doi:10.1017/S0954579404040167

Schulenberg, J., \& Maggs, J. (2002). A developmental perspective on alcohol use and heavy drinking during adolescence and the transition to young adulthood. Journal of Studies on Alcohol and Drugs(14), 54.

Seiffge-Krenke, I., \& Gelhaar, T. (2008). Does successful attainment of developmental tasks lead to happiness and success in later developmental tasks? A test of Havighurst's (1948) theses. Journal of adolescence, 31(1), 33-52.

Seligman, M. (2011). Flourish. London: Nicholas Brealey Pub.

Seligman, M., Ernst, R., Gillham, J., Reivich, K., \& Linkins, M. (2009). Positive education: Positive psychology and classroom interventions. Oxford Review of Education, 35, 293-311.

Settersten, R. (2005). Social Policy and the transition to Adulthood. On the frontier of adulthood: Theory, research, and public policy, 534-560.

Smith, E. (1999). The effects of investments in the social capital of youth on political and civic behavior in young adulthood: A longitudinal analysis. Political Psychology, 20, 553-580. 
Stone, W., \& Hughes, J. (2002). Social capital: Empirical meaning and measurement validity (pp. 1-64). (Working Paper No. 27). Melbourne, Victoria: Australian Institute of Family Studies.

Suldo, S. M., Thalji, A., \& Ferron, J. (2011). Longitudinal academic outcomes predicted by early adolescents' subjective well-being, psychopathology, and mental health status yielded from a dual factor model. Journal of Positive Psychology, 6, 17-30.

Tabachnick, B., \& Fidell, L. (2001). Using multivariate statistics (4th ed.). Boston: Allyn \& Bacon.

Vujeva, H. M., \& Furman, W. (2011). Depressive Symptoms and Romantic Relationship Qualities from Adolescence through Emerging Adulthood: A Longitudinal Examination of Influences. Journal of Clinical Child and Adolescent Psychology, 40(1), 123-135.

Watts, M. J., \& Mitchell, W. F. (2000). The costs of unemployment in Australia. The Economic and Labour Relations Review, 11(2), 180-197.

Table 1. Summary of measures used in the current study.

\begin{tabular}{|c|c|c|c|c|c|c|c|c|}
\hline Domain & Indicator & Age & $\begin{array}{l}\text { Infor } \\
\text { mant }\end{array}$ & $\begin{array}{l}\text { No. } \\
\text { of } \\
\text { ite } \\
\text { ms }\end{array}$ & Example item & Scale & $\begin{array}{l}\text { Reliabil } \\
\text { ity } \\
\text { (Cronb } \\
\text { ach's } \\
\alpha \text { ) }\end{array}$ & $\begin{array}{c}\text { M(SD) } \\
\text { or } \%\end{array}$ \\
\hline \multicolumn{9}{|c|}{ Positive mental health in adolescence } \\
\hline $\begin{array}{l}\text { Positive } \\
\text { Emotions } \\
\text { (capacity } \\
\text { for } \\
\text { emotional } \\
\text { regulation } \\
\text { ) }\end{array}$ & $\begin{array}{l}\text { ATP devised } \\
\text { Emotional } \\
\text { Control scale }\end{array}$ & $\begin{array}{l}15- \\
16 \\
\text { year } \\
\text { s }\end{array}$ & $\begin{array}{l}\text { Study } \\
\text { child }\end{array}$ & 10 & $\begin{array}{l}\text { "When things } \\
\text { go wrong I try } \\
\text { to stay } \\
\text { optimistic" }\end{array}$ & $\begin{array}{l}1 \text { =Never } \\
\text { to } \\
6=\text { Always }\end{array}$ & .70 & $\begin{array}{l}\mathrm{M}=3.74 \\
; \\
\mathrm{SD}=.58\end{array}$ \\
\hline $\begin{array}{l}\text { Engagem } \\
\text { ent } \\
\text { (Interest, } \\
\text { engagem }\end{array}$ & $\begin{array}{l}\text { Short form of } \\
\text { ACER } \\
\text { School Life } \\
\text { Questionnair }\end{array}$ & $\begin{array}{l}15- \\
16 \\
\text { year } \\
\text { s }\end{array}$ & $\begin{array}{l}\text { Study } \\
\text { child }\end{array}$ & $\begin{array}{l}5 ; \\
4\end{array}$ & $\begin{array}{l}\text { "I find that } \\
\text { learning is a lot } \\
\text { of fun"; "The } \\
\text { things I am }\end{array}$ & $\begin{array}{l}1=\text { Definitel } \\
\text { y agree to } \\
4=\text { Definitel } \\
\text { y disagree }\end{array}$ & $.86 ; .81$ & $\begin{array}{l}\mathrm{M}=.00 \\
\mathrm{SD}=.83\end{array}$ \\
\hline
\end{tabular}




\begin{tabular}{|c|c|c|c|c|c|c|c|c|}
\hline Domain & Indicator & Age & $\begin{array}{l}\text { Infor } \\
\text { mant }\end{array}$ & $\begin{array}{l}\text { No. } \\
\text { of } \\
\text { ite } \\
\text { ms }\end{array}$ & Example item & Scale & $\begin{array}{l}\text { Reliabil } \\
\text { ity } \\
\text { (Cronb } \\
\text { ach's } \\
\text { a) }\end{array}$ & $\begin{array}{c}\text { M(SD) } \\
\text { or \% }\end{array}$ \\
\hline $\begin{array}{l}\text { ent, } \\
\text { curiosity } \\
\text { and } \\
\text { absorptio } \\
\text { n) }\end{array}$ & $\begin{array}{l}\text { e-Positive } \\
\text { affect and } \\
\text { Long-term } \\
\text { relevance of } \\
\text { schooling } \\
\text { subscales } \\
\text { (Ainley et al. } \\
\text { 1984) }\end{array}$ & & & & $\begin{array}{l}\text { taught are } \\
\text { worthwhile } \\
\text { learning" }\end{array}$ & & & \\
\hline $\begin{array}{l}\text { Relations } \\
\text { hips } \\
\text { (Social } \\
\text { skills to } \\
\text { foster } \\
\text { positive } \\
\text { relationshi } \\
\text { ps) }\end{array}$ & $\begin{array}{l}\text { Social skills } \\
\text { rating system } \\
\text { - Self control } \\
\text { and } \\
\text { Responsibilit } \\
\text { y subscales } \\
\text { (Gresham } \\
\text { and Elliot } \\
1990 \text { ) }\end{array}$ & $\begin{array}{l}15- \\
16 \\
\text { year } \\
\mathrm{s}\end{array}$ & $\begin{array}{l}\text { Paren } \\
\mathrm{t}\end{array}$ & 7 & $\begin{array}{l}\text { "Controls } \\
\text { temper when } \\
\text { arguing with } \\
\text { other young } \\
\text { people" }\end{array}$ & $\begin{array}{l}0=\text { Rarely/ } \\
\text { Never, } \\
1=\text { Someti } \\
\text { mes, } \\
2=\text { Often/al } \\
\text { ways }\end{array}$ & .76 & $\begin{array}{l}\mathrm{M}=1.15 \\
\mathrm{SD}=.36\end{array}$ \\
\hline $\begin{array}{l}\text { Purpose } \\
\text { (meaningf } \\
\text { ul } \\
\text { contributio } \\
n \text { to } \\
\text { others } \\
\text { and } \\
\text { communit } \\
\text { y) }\end{array}$ & $\begin{array}{l}\text { ATP devised } \\
\text { Prosocial/Co } \\
\text { mmunity } \\
\text { Civic } \\
\text { Responsibilit } \\
\text { y scale }\end{array}$ & $\begin{array}{l}15- \\
16 \\
\text { year } \\
\text { s }\end{array}$ & $\begin{array}{l}\text { Study } \\
\text { child }\end{array}$ & 6 & $\begin{array}{l}\text { "I take part in } \\
\text { fund-raising } \\
\text { activities such } \\
\text { as the } 40-\text {-Hour } \\
\text { Famine or Walk } \\
\text { against Want" }\end{array}$ & $\begin{array}{l}0=\text { Rarely/ } \\
\text { Never, } \\
1=\text { Someti } \\
\text { mes, } \\
2=\text { Often/al } \\
\text { ways }\end{array}$ & .65 & $\begin{array}{l}M=.65 \\
S D=.36\end{array}$ \\
\hline $\begin{array}{l}\text { Accomplis } \\
\text { hment } \\
\text { (striving } \\
\text { for and } \\
\text { achieving } \\
\text { meaningf } \\
\text { ul goals) }\end{array}$ & $\begin{array}{l}\text { Confidence } \\
\text { in } \\
\text { ability/succes } \\
\text { s subscale } \\
\text { from the } \\
\text { Short form of } \\
\text { the ACER } \\
\text { School Life } \\
\text { Questionnair } \\
\text { e (Ainley et } \\
\text { al. 1984) }\end{array}$ & $\begin{array}{l}15- \\
16 \\
\text { year } \\
\text { s }\end{array}$ & $\begin{array}{l}\text { Study } \\
\text { child }\end{array}$ & 5 & $\begin{array}{l}\text { "My school is a } \\
\text { place where I } \\
\text { have learnt to } \\
\text { work hard" }\end{array}$ & $\begin{array}{l}\text { 1=Definitel } \\
\text { y agree to } \\
4=\text { Definitel } \\
\text { y disagree }\end{array}$ & .83 & $\begin{array}{l}\mathrm{M}=3.16 \\
\mathrm{SD}=.48\end{array}$ \\
\hline $\begin{array}{l}\text { Health } \\
\text { (health } \\
\text { risk } \\
\text { behaviors } \\
\text { ) }\end{array}$ & $\begin{array}{l}\text { ATP devised } \\
\text { health risk } \\
\text { behaviors }\end{array}$ & $\begin{array}{l}15- \\
16 \\
\text { year } \\
\text { s }\end{array}$ & $\begin{array}{l}\text { Study } \\
\text { child }\end{array}$ & 5 & $\begin{array}{l}\text { Has smoked } \\
\text { more than } 2 \\
\text { cigarettes in life } \\
\text { (yes/no); Has } \\
\text { drunk alcohol } \\
\text { more than two } \\
\text { times in life } \\
\text { (yes/no); Crash } \\
\text { diets to lose } \\
\text { weight }\end{array}$ & $\begin{array}{l}\text { Yes/no; } \\
1=\text { never, } \\
2=0 c c a s i o \\
\text { nally, } \\
\text { 3=weekly, } \\
\text { 4=daily }\end{array}$ & - & $\begin{array}{l}M=.00 \\
S D=.66\end{array}$ \\
\hline \multicolumn{9}{|c|}{ Developmental tasks in young adulthood } \\
\hline $\begin{array}{l}\text { Establishi } \\
\text { ng a } \\
\text { career }\end{array}$ & $\begin{array}{l}\text { Highest level } \\
\text { of education } \\
\text { completed } \\
\text { (ATP- } \\
\text { devised item) }\end{array}$ & $\begin{array}{l}27- \\
28 \\
\text { year } \\
\mathrm{s}\end{array}$ & $\begin{array}{l}\text { Study } \\
\text { young } \\
\text { adult }\end{array}$ & 1 & $\begin{array}{l}\text { Highest } \\
\text { educational } \\
\text { qualification } \\
\text { achieved to } \\
\text { date }\end{array}$ & $\begin{array}{l}1=\text { Years } \\
8-10 \text { of } \\
\text { secondary } \\
\text { school to } \\
10=\text { Postgr } \\
\text { aduate }\end{array}$ & - & $\begin{array}{l}M=5.90 \\
S \\
9\end{array}$ \\
\hline
\end{tabular}




\begin{tabular}{|c|c|c|c|c|c|c|c|c|}
\hline \multirow[t]{4}{*}{ Domain } & Indicator & Age & $\begin{array}{l}\text { Infor } \\
\text { mant }\end{array}$ & $\begin{array}{l}\text { No. } \\
\text { of } \\
\text { ite } \\
\text { ms }\end{array}$ & Example item & Scale & $\begin{array}{l}\text { Reliabil } \\
\text { ity } \\
\text { (Cronb } \\
\text { ach's } \\
\text { a) }\end{array}$ & $\begin{array}{l}\text { M(SD) } \\
\text { or } \%\end{array}$ \\
\hline & & & & & & $\begin{array}{l}\text { qualificatio } \\
\mathrm{n}\end{array}$ & & \\
\hline & $\begin{array}{l}\text { Satisfaction } \\
\text { with job } \\
\text { (adapted } \\
\text { from the } \\
\text { National } \\
\text { Survey of } \\
\text { Families and } \\
\text { Households } \\
\text { (1996) and } \\
\text { Christchurch } \\
\text { Health and } \\
\text { Development } \\
\text { Study 21 } \\
\text { Year } \\
\text { Interview) }\end{array}$ & $\begin{array}{l}27- \\
28 \\
\text { year } \\
\text { s }\end{array}$ & $\begin{array}{l}\text { Study } \\
\text { young } \\
\text { adult }\end{array}$ & 1 & $\begin{array}{l}\text { "Thinking about } \\
\text { your own life } \\
\text { and personal } \\
\text { circumstances, } \\
\text { how satisfied } \\
\text { are you with the } \\
\text { work you do } \\
\text { (paid or at } \\
\text { home)" }\end{array}$ & $\begin{array}{l}1=\text { Very } \\
\text { satisfied to } \\
4=\text { Not at } \\
\text { all } \\
\text { satisfied }\end{array}$ & - & $\begin{array}{l}\mathrm{M}=1.93 \\
; \\
\mathrm{SD}=.73\end{array}$ \\
\hline & $\begin{array}{l}\text { Perceived } \\
\text { competence } \\
\text { (ATP } \\
\text { devised) }\end{array}$ & $\begin{array}{l}27- \\
28 \\
\text { year } \\
\mathrm{s}\end{array}$ & $\begin{array}{l}\text { Study } \\
\text { young } \\
\text { adult }\end{array}$ & 1 & $\begin{array}{l}\text { "People at work } \\
\text { tell me I am } \\
\text { good at what I } \\
\text { do" }\end{array}$ & $\begin{array}{l}1=\text { Not at } \\
\text { all true to } \\
5=\text { Very } \\
\text { true }\end{array}$ & - & $\begin{array}{l}\mathrm{M}=4.15 \\
; \\
\mathrm{SD}=.89\end{array}$ \\
\hline \multirow[t]{4}{*}{$\begin{array}{l}\text { Forming } \\
\text { romantic } \\
\text { partnershi } \\
\text { ps }\end{array}$} & $\begin{array}{l}\text { In a romantic } \\
\text { relationship }\end{array}$ & $\begin{array}{l}23- \\
24 \\
\text { year } \\
\text { s }\end{array}$ & $\begin{array}{l}\text { Study } \\
\text { young } \\
\text { adult }\end{array}$ & 1 & $\begin{array}{l}\text { Are you } \\
\text { currently: (circle } \\
\text { one) } \\
\text { 1=Not } \\
\text { seeing/dating } \\
\text { anyone; } \\
\text { 2=Dating one or } \\
\text { more people } \\
\text { casually; } 3=\text { In a } \\
\text { committed } \\
\text { relationship } \\
\text { (opposite sex); } \\
\text { 4=In a } \\
\text { committed } \\
\text { relationship } \\
\text { (same sex) }\end{array}$ & $\begin{array}{l}\text { Response } \\
\text { s } 3 \text { and } 4 \\
\text { coded as } \\
\text { currently } \\
\text { in a } \\
\text { relationshi } \\
\mathrm{p}\end{array}$ & - & $\begin{array}{l}69.40 \% \\
\text { currentl } \\
\text { y in a } \\
\text { relation } \\
\text { ship }\end{array}$ \\
\hline & $\begin{array}{l}\text { Relationship } \\
\text { quality } \\
\text { (Braiker and } \\
\text { Kelley 1979) }\end{array}$ & $\begin{array}{l}23- \\
24 \\
\text { year } \\
\mathrm{s}\end{array}$ & $\begin{array}{l}\text { Study } \\
\text { young } \\
\text { adult }\end{array}$ & 6 & $\begin{array}{l}\text { "I have a sense } \\
\text { of 'belonging' } \\
\text { with my } \\
\text { partner" }\end{array}$ & $\begin{array}{l}\text { 1=Always } \\
\text { to } \\
4=\text { Rarely/ } \\
\text { Never }\end{array}$ & .86 & $\begin{array}{l}\mathrm{M}=3.56 \\
; \\
\mathrm{SD}=.50\end{array}$ \\
\hline & $\begin{array}{l}\text { In a romantic } \\
\text { relationship } \\
\text { (as for 23-24 } \\
\text { years) }\end{array}$ & $\begin{array}{l}27- \\
28 \\
\text { year } \\
\mathrm{s}\end{array}$ & $\begin{array}{l}\text { Study } \\
\text { young } \\
\text { adult }\end{array}$ & 1 & $\begin{array}{l}\text { As for 23-24 } \\
\text { years }\end{array}$ & & - & $\begin{array}{l}73.50 \% \\
\text { currentl } \\
\text { y in a } \\
\text { relation } \\
\text { ship }\end{array}$ \\
\hline & $\begin{array}{l}\text { Relationship } \\
\text { quality (as } \\
\text { for } 23-24 \\
\text { years) }\end{array}$ & $\begin{array}{l}27- \\
28 \\
\text { year } \\
\text { S }\end{array}$ & $\begin{array}{l}\text { Study } \\
\text { young } \\
\text { adult }\end{array}$ & 6 & $\begin{array}{l}\text { As for 23-24 } \\
\text { years }\end{array}$ & & .85 & $\begin{array}{l}\mathrm{M}=3.63 \\
; \\
\mathrm{SD}=.46\end{array}$ \\
\hline $\begin{array}{l}\text { Taking on } \\
\text { citizenshi } \\
p \\
\text { responsibi }\end{array}$ & $\begin{array}{l}\text { Volunteering } \\
\text { or } \\
\text { community } \\
\text { service }\end{array}$ & $\begin{array}{l}23- \\
24 \\
\text { year } \\
\text { s }\end{array}$ & $\begin{array}{l}\text { Study } \\
\text { Young } \\
\text { Adult }\end{array}$ & 14 & $\begin{array}{l}\text { "How often in } \\
\text { the past } 12 \\
\text { months have } \\
\text { you worked as }\end{array}$ & $\begin{array}{l}1=\text { Never } \\
\text { to } \\
5=\text { Weekly } \\
\text { or more }\end{array}$ & .61 & $\begin{array}{l}M=.17 \\
S D=.41\end{array}$ \\
\hline
\end{tabular}




\begin{tabular}{|c|c|c|c|c|c|c|c|c|}
\hline Domain & Indicator & Age & $\begin{array}{l}\text { Infor } \\
\text { mant }\end{array}$ & $\begin{array}{l}\text { No. } \\
\text { of } \\
\text { ite } \\
\text { ms }\end{array}$ & Example item & Scale & $\begin{array}{l}\text { Reliabil } \\
\text { ity } \\
\text { (Cronb } \\
\text { ach's } \\
\text { a) }\end{array}$ & $\begin{array}{c}\text { M(SD) } \\
\text { or } \%\end{array}$ \\
\hline \multirow[t]{4}{*}{ lities } & $\begin{array}{l}\text { adapted } \\
\text { from Stone } \\
\text { and Hughes } \\
2002)\end{array}$ & & & & $\begin{array}{l}\text { a volunteer } \\
\text { (unpaid) for } \\
\text { these groups? } \\
\text {.. Human } \\
\text { rights, } \\
\text { community or } \\
\text { welfare group" }\end{array}$ & & & \\
\hline & $\begin{array}{l}\text { Engagement } \\
\text { in civic } \\
\text { activities } \\
\text { (adapted } \\
\text { from Stone } \\
\text { and Hughes } \\
2002 \text { ) }\end{array}$ & $\begin{array}{l}23- \\
24 \\
\text { year } \\
\text { s }\end{array}$ & $\begin{array}{l}\text { Study } \\
\text { Young } \\
\text { Adult }\end{array}$ & 18 & $\begin{array}{l}\text { "In the past } 12 \\
\text { months have } \\
\text { you...Served or } \\
\text { assisted as a } \\
\text { volunteer } \\
\text { mentor, tutor, } \\
\text { coach or } \\
\text { counsellor" }\end{array}$ & $\begin{array}{l}\text { No, } 1-2 \\
\text { times, 3-4 } \\
\text { times, or } \\
5+\text { times }\end{array}$ & .74 & $\begin{array}{l}\mathrm{M}=1.54 \\
; \\
\mathrm{SD}=.33\end{array}$ \\
\hline & $\begin{array}{l}\text { Volunteering } \\
\text { or } \\
\text { community } \\
\text { service } \\
\text { (adapted } \\
\text { from Stone } \\
\text { and Hughes } \\
\text { 2002) }\end{array}$ & $\begin{array}{l}27- \\
28 \\
\text { year } \\
\text { s }\end{array}$ & $\begin{array}{l}\text { Study } \\
\text { Young } \\
\text { Adult }\end{array}$ & 14 & $\begin{array}{l}\text { "In the past } 12 \\
\text { months were a } \\
\text { member of } \\
\text { these groups, } \\
\text { participated in } \\
\text { any of these } \\
\text { groups, or have } \\
\text { worked as an } \\
\text { unpaid } \\
\text { volunteer for } \\
\text { any of these } \\
\text { groups... } \\
\text { Human rights, } \\
\text { community or } \\
\text { welfare group" }\end{array}$ & Yes/no & .60 & $\begin{array}{l}M=.38 \\
S D=.49\end{array}$ \\
\hline & $\begin{array}{l}\text { Engagement } \\
\text { in civic } \\
\text { activities } \\
\text { (adapted } \\
\text { from Stone } \\
\text { and Hughes } \\
\text { 2002) }\end{array}$ & $\begin{array}{l}27- \\
28 \\
\text { year } \\
\text { s }\end{array}$ & $\begin{array}{l}\text { Study } \\
\text { Young } \\
\text { Adult }\end{array}$ & 16 & $\begin{array}{l}\text { "Served or } \\
\text { assisted as a } \\
\text { volunteer } \\
\text { mentor, tutor, } \\
\text { coach or } \\
\text { counsellor" }\end{array}$ & $\begin{array}{l}\text { No, } 1-2 \\
\text { times, 3-4 } \\
\text { times, 5- } \\
10 \text { times, } \\
11+\text { times }\end{array}$ & .70 & $\begin{array}{l}\mathrm{M}=1.61 \\
; \\
\mathrm{SD}=.38\end{array}$ \\
\hline \multicolumn{9}{|l|}{$\begin{array}{l}\text { Control } \\
\text { variables }\end{array}$} \\
\hline $\begin{array}{l}\text { Demogra } \\
\text { phics }\end{array}$ & $\begin{array}{l}\begin{array}{l}\text { Child's } \\
\text { gender }\end{array} \\
\text { Family } \\
\text { socioeconom } \\
\text { ic position }\end{array}$ & $\begin{array}{l}\text { Infa } \\
\text { ncy } \\
15- \\
16 \\
\text { year } \\
\text { s }\end{array}$ & $\begin{array}{l}\text { Paren } \\
t \\
\text { Paren } \\
t\end{array}$ & 1 & $\begin{array}{l}\text { Gender } \\
\text { Composite of } \\
\text { both parents' } \\
\text { educational } \\
\text { level and } \\
\text { occupational } \\
\text { level (adapted } \\
\text { from Brotherton } \\
\text { et al. 1979; } \\
\text { Broom et al. } \\
\text { 1976) }\end{array}$ & $\begin{array}{l}\text { Boy/girl } \\
\text { Education: } \\
\text { 8-point } \\
\text { scale from } \\
\text { 'primary' } \\
\text { to } \\
\text { 'postgradu } \\
\text { ate' level. } \\
\text { Occupatio } \\
\text { nal level: } \\
\text { 8-point } \\
\text { scale from } \\
\text { 'housewife } \\
\text { / student/ } \\
\text { unemploy }\end{array}$ & - & $\begin{array}{l}60.40 \% \\
\text { female } \\
M=3.93 \\
; \\
S D=1.4 \\
6\end{array}$ \\
\hline
\end{tabular}




\begin{tabular}{|c|c|c|c|c|c|c|c|c|}
\hline \multirow[t]{3}{*}{ Domain } & Indicator & Age & $\begin{array}{l}\text { Infor } \\
\text { mant }\end{array}$ & $\begin{array}{l}\text { No. } \\
\text { of } \\
\text { ite } \\
\text { ms }\end{array}$ & Example item & Scale & $\begin{array}{l}\text { Reliabil } \\
\text { ity } \\
\text { (Cronb } \\
\text { ach's } \\
\text { a) }\end{array}$ & $\begin{array}{c}\text { M(SD) } \\
\text { or \% }\end{array}$ \\
\hline & & & & & & $\begin{array}{l}\text { ed' to } \\
\text { 'upper } \\
\text { profession } \\
\text { al. }\end{array}$ & & \\
\hline & $\begin{array}{l}\text { Family } \\
\text { structure }\end{array}$ & $\begin{array}{l}15- \\
16 \\
\text { year } \\
\text { s }\end{array}$ & $\begin{array}{l}\text { Paren } \\
\mathrm{t}\end{array}$ & 1 & $\begin{array}{l}\text { Who child lived } \\
\text { with at } 15-16 \\
\text { years }\end{array}$ & & - & $\begin{array}{l}81.3 \% \\
2- \\
\text { parent } \\
\text { househ } \\
\text { old }\end{array}$ \\
\hline \multirow[t]{4}{*}{$\begin{array}{l}\text { Family } \\
\text { stress }\end{array}$} & Family stress & $\begin{array}{l}15- \\
16 \\
\text { year } \\
\text { s }\end{array}$ & $\begin{array}{l}\text { Paren } \\
\mathrm{t}\end{array}$ & 1 & $\begin{array}{l}\text { Total number of } \\
\text { negative family } \\
\text { changes/losses } \\
\text { /problems in } \\
\text { past } 12 \text { months }\end{array}$ & & - & $\begin{array}{l}M=.34 \\
S D=.72\end{array}$ \\
\hline & $\begin{array}{l}\text { Parental } \\
\text { unemployme } \\
\text { nt }\end{array}$ & $\begin{array}{l}15- \\
16 \\
\text { year } \\
\mathrm{s}\end{array}$ & $\begin{array}{l}\text { Paren } \\
\mathrm{t}\end{array}$ & 1 & $\begin{array}{l}\text { Was an ATP } \\
\text { parent } \\
\text { unemployed } \\
\text { during the past } \\
\text { year? }\end{array}$ & $\begin{array}{l}\text { Neither; } \\
\text { Mother; } \\
\text { Father }\end{array}$ & - & $\begin{array}{l}12.3 \% \\
\text { one or } \\
\text { both } \\
\text { parents } \\
\text { unempl } \\
\text { oyed in } \\
\text { past } \\
\text { year }\end{array}$ \\
\hline & $\begin{array}{l}\text { House } \\
\text { moves }\end{array}$ & $\begin{array}{l}15- \\
16 \\
\text { year } \\
\mathrm{s}\end{array}$ & $\begin{array}{l}\text { Paren } \\
\mathrm{t}\end{array}$ & 1 & $\begin{array}{l}\text { Number of } \\
\text { house moves } \\
\text { during child's } \\
\text { life }\end{array}$ & & - & $\begin{array}{l}M=2.05 \\
; \\
9\end{array}$ \\
\hline & $\begin{array}{l}\text { School } \\
\text { changes }\end{array}$ & $\begin{array}{l}15- \\
16 \\
\text { year } \\
\mathrm{s}\end{array}$ & $\begin{array}{l}\text { Paren } \\
\mathrm{t}\end{array}$ & 1 & $\begin{array}{l}\text { Number of } \\
\text { times child has } \\
\text { moved school } \\
\text { in lifetime }\end{array}$ & & - & $\begin{array}{l}M=1.65 \\
; \\
4\end{array}$ \\
\hline \multirow[t]{2}{*}{$\begin{array}{l}\text { Behaviora } \\
\text { I problems } \\
\text { in } \\
\text { adolescen } \\
\text { ce }\end{array}$} & $\begin{array}{l}\text { Depression } \\
\text { (Angold et al. } \\
\text { 1995) }\end{array}$ & $\begin{array}{l}15- \\
16 \\
\text { year } \\
\text { s }\end{array}$ & $\begin{array}{l}\text { Study } \\
\text { child }\end{array}$ & 12 & $\begin{array}{l}\text { "I do everything } \\
\text { wrong" }\end{array}$ & $\begin{array}{l}0=\text { Rarely/ } \\
\text { never, } \\
1=\text { Someti } \\
\text { mes, } \\
2=\text { Often, } \\
\text { Always }\end{array}$ & .85 & $\begin{array}{l}M=.48 \\
S D=.36\end{array}$ \\
\hline & $\begin{array}{l}\text { Anti-social } \\
\text { behaviors } \\
\text { (Moffitt and } \\
\text { Silva 1988) }\end{array}$ & $\begin{array}{l}15- \\
16 \\
\text { year } \\
\mathrm{s}\end{array}$ & $\begin{array}{l}\text { Study } \\
\text { child }\end{array}$ & 13 & $\begin{array}{l}\text { "In the past } 12 \\
\text { months, have } \\
\text { you done any of } \\
\text { the following?... } \\
\text { Stolen } \\
\text { something" }\end{array}$ & $\begin{array}{l}1=\text { not at } \\
\text { all, } 2= \\
\text { Once, } 3= \\
\text { twice, } 4= \\
\text { more often }\end{array}$ & .82 & $\begin{array}{l}\mathrm{M}=1.22 \\
; \\
\mathrm{SD}=.34\end{array}$ \\
\hline
\end{tabular}


Table 2. Positive mental health at 15-16 years as a predictor of success in establishing a career at $27-28$ years

\begin{tabular}{|c|c|c|c|}
\hline \multirow[b]{2}{*}{$\begin{array}{c}\text { Adolescent } \\
\text { characteristics }\end{array}$} & \multicolumn{3}{|c|}{ Young adult outcomes (27-28 years) } \\
\hline & $\begin{array}{c}\text { Highest level of } \\
\text { education achieved } \\
\beta(\mathrm{B}, \mathrm{SE})\end{array}$ & $\begin{array}{l}\text { Competence in } \\
\text { current job } \\
\beta(\mathrm{B}, \mathrm{SE})\end{array}$ & $\begin{array}{c}\text { Overall satisfaction with } \\
\text { current job } \\
\beta(\mathrm{B}, \mathrm{SE})\end{array}$ \\
\hline $\begin{array}{l}\text { Positive mental health } \\
\text { Demographics }\end{array}$ & $.21(1.33, .24)^{\star \star}$ & $.11(.27, .11)^{*}$ & $.08(.10, .06)$ \\
\hline Female gender & $.05(.22, .15)$ & $.10(.17, .07)^{\star}$ & $.06(.06, .04)$ \\
\hline $\begin{array}{l}\text { Socioeconomic } \\
\text { disadvantage }\end{array}$ & $-.28(-.42, .05)^{\star \star}$ & $.05(.03, .02)$ & $.05(.02, .01)$ \\
\hline Family composition & $.02(.12, .18)$ & $-.01(-.03, .08)$ & .06 (.06, .04) \\
\hline Family stress & & & \\
\hline $\begin{array}{l}\text { Family stress } \\
\text { Parental } \\
\text { unemployment }\end{array}$ & $\begin{array}{l}-.01(-.03, .10) \\
-.05(-.35, .22)\end{array}$ & $\begin{array}{l}-.03(-.04, .04) \\
.00(-.02, .10)\end{array}$ & $\begin{array}{l}-.02(-.02, .02) \\
-.06(-.09, .05)\end{array}$ \\
\hline House moves & $-.07(-.06, .04)$ & $-.04(-.02, .02)$ & $-.03(-.01, .01)$ \\
\hline School changes & $-.03(-.04, .07)$ & $-.01(-.01, .03)$ & $.00(.00, .02)$ \\
\hline Behavioral problems & & & \\
\hline Depression & $-.02(-.14, .23)$ & $-.06(-.15, .11)$ & $-.10(-.12, .05)^{*}$ \\
\hline Anti-social behaviors & $-.12(-.78, .24)^{\star \star}$ & $.04(.10, .11)$ & $.06(.09, .06)$ \\
\hline Model $R^{2}$ & .20 & .03 & .03 \\
\hline
\end{tabular}

$*=p<.05, * *=p<.01$. 
Table 3. Positive mental health at 15-16 years as a predictor of success in forming romantic relationships at 23-24 and 27-28 years

\begin{tabular}{|c|c|c|c|c|}
\hline \multirow[b]{3}{*}{ Adolescent characteristics } & \multicolumn{4}{|c|}{ Young adult outcomes } \\
\hline & \multicolumn{2}{|c|}{ 23-24 years } & \multicolumn{2}{|c|}{$27-28$ years } \\
\hline & $\begin{array}{c}\text { In a } \\
\text { relationship } \\
\text { OR }(95 \% \mathrm{Cl})\end{array}$ & $\begin{array}{c}\text { Relationship } \\
\text { quality } \\
\beta(B, S E)\end{array}$ & $\begin{array}{c}\text { In a } \\
\text { relationship } \\
\text { OR }(95 \% \mathrm{Cl})\end{array}$ & $\begin{array}{c}\text { Relationship } \\
\text { quality } \\
\beta(B, S E)\end{array}$ \\
\hline Positive mental health & $.69(.39,1.21)$ & $.03(.04, .08)$ & $1.30(.72,2.32)$ & $.04(.06, .07)$ \\
\hline $\begin{array}{l}\text { Demographics } \\
\text { Female gender }\end{array}$ & $\begin{array}{l}1.59(1.14 \\
2.23)^{\star \star}\end{array}$ & $.12(.11, .05)^{\star}$ & $1.19(.83,1.71)$ & $.08(.04, .09)$ \\
\hline $\begin{array}{l}\text { Socioeconomic } \\
\text { disadvantage }\end{array}$ & $1.05(.94,1.17)$ & $.07(.03, .02)$ & $\begin{array}{c}1.18(1.05 \\
1.34)^{* *}\end{array}$ & $.03(.01, .02)$ \\
\hline Family composition & $.92(.61,1.41)$ & . $05(.07, .06)$ & $1.05(.68,1.62)$ & $.02(.02, .05)$ \\
\hline \multicolumn{5}{|l|}{ Family stress } \\
\hline Family stress & $.10(.79,1.26)$ & $-.04(-.03, .03)$ & $1.16(.90,1.49)$ & $-.09(-.06, .03)$ \\
\hline Parental unemployment & $1.07(.64,1.78)$ & $-.01(-.01, .07)$ & $.81(.48,1.36)$ & $-.05(-.08, .06)$ \\
\hline House moves & $1.01(.94,1.10)$ & $.04(.01, .01)$ & $.96(.89,1.05)$ & $.00(.00, .01)$ \\
\hline School changes & $1.00(.86,1.16)$ & $-.03(-.01, .02)$ & $1.01(.86,1.18)$ & $-.02(-.01, .02)$ \\
\hline \multicolumn{5}{|l|}{ Behavioral problems } \\
\hline Depression & $1.13(.67,1.92)$ & $-.21(-.30, .07)^{\star *}$ & $.85(.48,1.43)$ & $-.13(-.17, .07)^{\star *}$ \\
\hline Anti-social behaviors & $\begin{array}{c}2.03(1.09 \\
3.77)^{\star}\end{array}$ & $-.01(-.01, .07)$ & $\begin{array}{c}2.05(1.06 \\
3.98)^{\star}\end{array}$ & $.02(.03, .07)$ \\
\hline Model $R^{2}$ & - & .06 & - & .04 \\
\hline
\end{tabular}

$*=p<.05, * *=p<.01$. 
Table 4. Positive mental health at 15-16 years as a predictor of success in taking on citizenship responsibilities at 23-24 and 27-28 years

\begin{tabular}{|c|c|c|c|c|}
\hline \multirow{4}{*}{$\begin{array}{c}\text { Adolescent } \\
\text { characteristics }\end{array}$} & \multicolumn{4}{|c|}{ Young adult outcomes } \\
\hline & \multicolumn{2}{|c|}{$23-24$ years } & \multicolumn{2}{|c|}{$27-28$ years } \\
\hline & Volunteering & Engagement in civic & Volunteering & Engagement in civic \\
\hline & $\beta(\mathrm{B}, \mathrm{SE})$ & $\begin{array}{l}\text { activities } \\
\beta(\mathrm{B}, \mathrm{SE})\end{array}$ & $\beta(\mathrm{B}, \mathrm{SE})$ & $\begin{array}{l}\text { activities } \\
\beta(\mathrm{B}, \mathrm{SE})\end{array}$ \\
\hline Positive mental health & $\begin{array}{c}-.01(-.01 \\
.05)\end{array}$ & $.11(.11, .04)^{\star \star}$ & $.09(.12, .06)^{\star}$ & $.17(.19, .05)^{\star \star}$ \\
\hline \multicolumn{5}{|l|}{ Demographics } \\
\hline Female gender & $.03(.03, .03)$ & $.14(.09, .03)^{\star *}$ & $\begin{array}{c}-.08(-.08 \\
.04)\end{array}$ & $.13(.10, .03)^{\star \star}$ \\
\hline $\begin{array}{l}\text { Socioeconomic } \\
\text { disadvantage }\end{array}$ & $\begin{array}{c}.08(.02 \\
.01)^{*}\end{array}$ & $-.14(-.03, .01)^{\star *}$ & $\begin{array}{c}-.08(-.03 \\
.01)^{*}\end{array}$ & $-.12(-.03, .01)^{\star \star}$ \\
\hline Family composition & $\begin{array}{c}-.03(-.03 \\
.04)\end{array}$ & $-.01(-.01, .03)$ & $.04(.05, .05)$ & $.01(.01, .04)$ \\
\hline \multicolumn{5}{|l|}{ Family stress } \\
\hline Family stress & $\begin{array}{c}-.01(-.01 \\
.02)\end{array}$ & $.09(.04, .02)^{*}$ & $.00(.00, .03)$ & $.02(.01, .02)$ \\
\hline $\begin{array}{l}\text { Parental } \\
\text { unemployment }\end{array}$ & $\begin{array}{l}.10(.13 \\
.05)^{* *}\end{array}$ & $-.04(-.04, .04)$ & $.06(.09, .06)$ & $.00(.00, .04)$ \\
\hline House moves & $\begin{array}{c}-.01(.00 \\
.01)\end{array}$ & $-.02(.00, .01)$ & $-.01(.00, .01)$ & $.00(.00, .01)$ \\
\hline School changes & $\begin{array}{c}-.06(-.02 \\
.01)\end{array}$ & $.00(.00, .01)$ & $\begin{array}{c}-.02(-.01 \\
.02)\end{array}$ & $.06(.02, .01)$ \\
\hline \multicolumn{5}{|l|}{ Behavioral problems } \\
\hline Depression & $.02(.02, .05)$ & $.04(.04, .04)$ & $.01(.02, .06)$ & $.03(.03, .05)$ \\
\hline Anti-social behaviors & $\begin{array}{c}-.06(-.07 \\
.05)\end{array}$ & $.04(.04, .04)$ & $\begin{array}{c}-.08(-.12 \\
.06)^{*}\end{array}$ & $.05(.07, .05)$ \\
\hline Model $R^{2}$ & .03 & .06 & .04 & .06 \\
\hline
\end{tabular}

$*=p<.05, * *=p<.01$. 


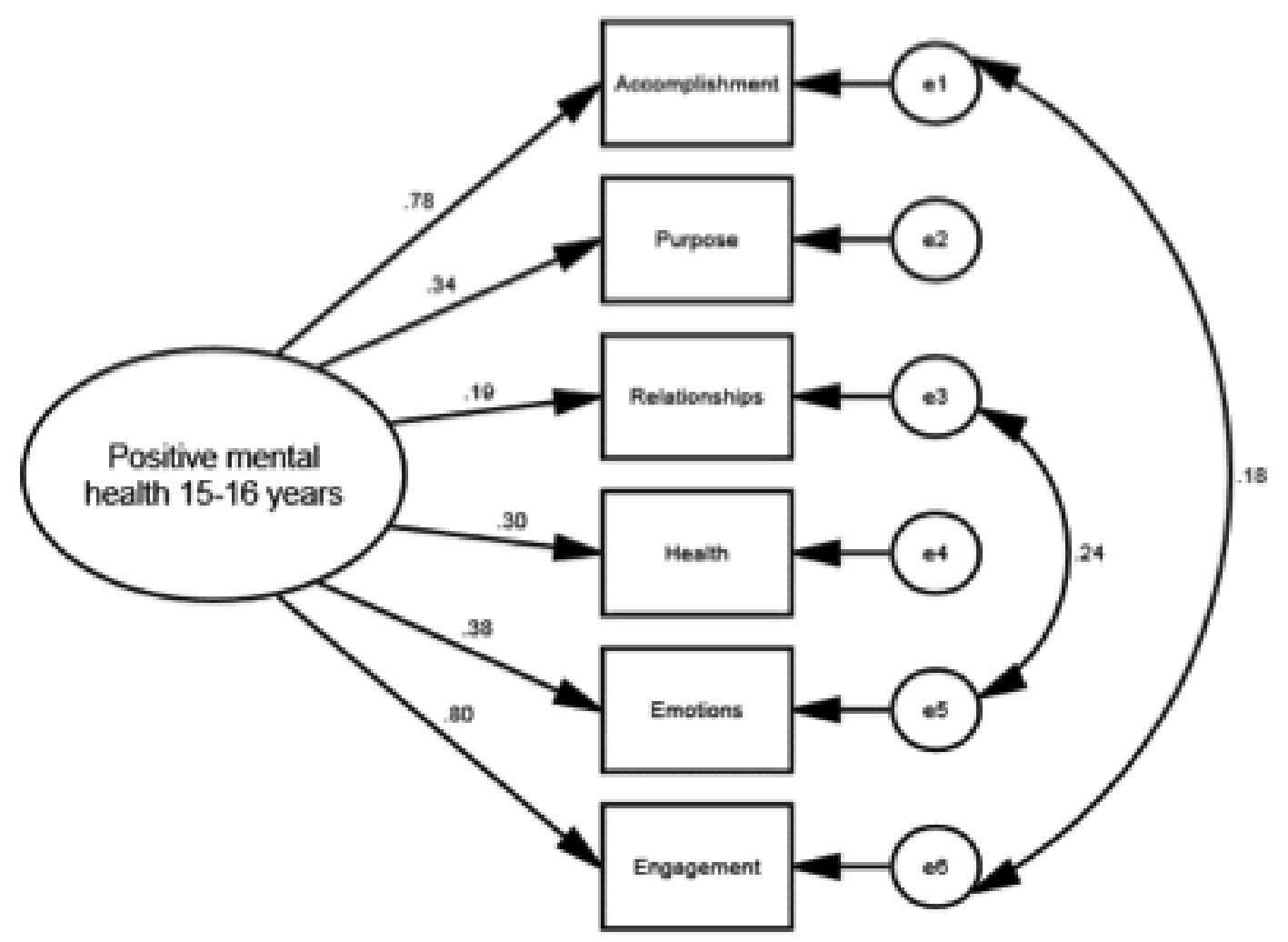

